\title{
FLORAL BIOLOGY STUDIES IN CERTAIN COMMERCIAL SPECIES OF JASMINE (JASMINUM SPP.)
}

\author{
J. LAKSHMI ${ }^{1} \&$ M. GANGA ${ }^{2}$ \\ ${ }^{1}$ Research Scholar, Department of Floriculture and Landscaping, Tamil Nadu Agricultural University, \\ Coimbatore, Tamil Nadu, India \\ ${ }^{2}$ Associate Professor (Horticulture) Horticultural Research Station, Ooty, Tamil Nadu Agricultural University,
}

Tamil Nadu, India

ABSTRACT
In any plant breeding program, knowledge of the floral biology of the species is an essential prerequisite. Floral
biology studies and information on flowering and fruiting season are required for a comprehensive understanding of
reproductive barriers. Jasmine is highly influenced by seasons, which profoundly affect the flowering and fruit set. The
floral biology of certain popular varieties belonging to the three most commercially important Jasminum species has been
documented and presented in this paper. Variations were observed for flower bud color, flowering season, pollen
production and fruit set potential. Two morphotypes of carpel namely, 'pin' and 'thrum' was observed in the
J. auriculatum genotypes.
KEYWORDS: Jasmine, Floral Dimorphism, Morphotypes \& Seed Set

Received: May 02, 2017; Accepted: Jun 01, 2017; Published: Jun 14, 2017; Paper Id.: IJASRJUN201757

\section{INTRODUCTION}

Jasmine (Jasminum spp.), is one of the oldest fragrant flowers cultivated by man. The different species of Jasminum are very favorite plants of horticulturists, chiefly due to the attractive fragrant flowers borne by them. They are extensively cultivated in gardens and nurseries throughout India, a factor which is largely responsible for the origin of a number of horticultural varieties of this genus.

Jasmine is widely cultivated in South India for use as garland, gajra and veni apart from concrete extraction. Jasmine belongs to the family Oleaceae. The Indian ornamental jasmine flower profusely, but set seed very rarely and are propagated chiefly by vegetative means. The facts of the antiquity of the genus and of its isolation from present day forms place it in a distinct morphological and cytological group, with an interesting floral biology.

In any plant breeding program, knowledge of the floral biology of the species is an essential prerequisite. The floral biology of certain popular varieties belonging to the three most commercially important Jasminum species has been documented and presented in this paper.

\section{MATERIALS AND METHODS}

The materials used for the study were three cultivars of J. auriculatum, two cultivars of J. grandiflorum and one cultivar of $J$. sambac. All the plants were grown in open field with uniform cultural conditions. 
Observations were recorded on flower diameter $(\mathrm{cm})$, corolla tube length $(\mathrm{cm})$, calyx type, mature flower bud color, open flower color, number of whorls of the corolla, number of petals per flower, number of pistils, style type, stigma tip, the number of anthers, length of the stamen $(\mathrm{cm})$, every type, flowering pattern, fruit setting potential and season of fruit set.

\section{RESULTS AND DISCUSSIONS}

The study of the factors influencing the adjustments of floral traits among species constitutes a central issue in comparative plant ecology. Knowledge on floral traits is essential for programming crop improvement through hybridization. Observations on the various floral biology parameters of jasmine genotypes are presented in Table 1.

All the genotypes studied had white flower buds except $J$. grandiflorum cv. CO.1 Pitchi, which was characterized by pink tinged buds. All the species consisted of two stamens (stamen length ranging from 1.24 to $1.72 \mathrm{~cm}$ ) and a single pistil. The stamens of the three cultivars of $J$. auriculatum and the two cultivars of $J$. grandiflorum contained higher pollen content whereas the pollen load was less in J. sambac. In J. auriculatum, floral dimorphism with respect to carpel was observed. Two morphotypes of carpel namely, 'pin' and 'thrum' were observed. J. auriculatum cv. CO.1 Mullai and cv. Pachaimullai were characterized by 'pin' type carpel with long style and short filament, where as J. auriculatum cv. Parimullai was characterized by 'thrum' type carpel with short style and long filament.

Floral dimorphism was reported in J.auriculatum by Raman et al. (1969). Bhupal Rao et al. (1977) reported floral dimorphism in $J$. grandiflorum and observed distinct differences in the flowering behavior of these two types. The long carpel (pin) type had prolific flowering, whereas the short carpel (thrum) type expressed shy flowering. Anthers are fixed onto the corolla by a very short filament. Two types of flower exist, always borne on separate plants. In the 'pin' form, the anthers are placed half-way down the corolla-tube, the mouth of which is occupied by the stigma tip protruding out, borne on the end of a long style. In the 'thrum' flowers, the positions of the sexual organs are reversed, the anthers being at the top of the corolla-tube while the stigma is half-way down it, since the style is relatively short.

The differences between morphs in stigma-anther separation were observed by Thompson (2000) in J. fruticans. The mutual relationship between the pin type and the thrum type flowers is improved as the stigma tip of long-styled plants, which is exerted beyond the mouth of the corolla and for a species with fixed anthers, that are already very close to the mouth of the corolla tube in short-styled plants, facilitating pollen flow among the morphs.

\section{CONCLUSIONS}

There was a marked variation in the period of peak flowering in the different genotypes (Figure 1). While the varieties of $J$. auriculatum recorded peak flowering during April to June, those of $J$. grandiflorum recorded peak flowering during August to January. The cv. Ramanathapuram Gundumalli of J. sambac recorded peak flowering during March to August. The seasonal variation of flowering in Jasminum species is due to the variations in photo-thermal units, which profoundly influence flowering. Similar findings were reported by Raman (1973) and Nedumaran (1977). Seed set was profuse in all the cultivars of $J$. auriculatum, whereas no seed set was present in the $J$. sambac cultivar. Similar findings were reported by Bhattacharjee (1978).

\section{REFERENCES}

1. Bhattacharjee, S.K. (1978). Jasmine- a most rewarding plant. Journal of Science Club, 32(3 \& 4):77-83. 
2. Bhupal Rao, J.V.R., Divakar, N.G. and Negi, S.S. (1977). Occurrence of floral dimorphism in Jasminum grandiflorum L. Indian Perfumer, 21(3): 160-161.

3. Monika Patel. (2013). Analysis of growth and yield performance of certain commercial jasmine (Jasminum spp.) varieties, M.Sc. Thesis, Tamil Nadu Agric. Univ. Coimbatore.

4. Neduraman, C. (1977). Effect of different dates of pruning on flower bud formation, growth and yield of flowers of jasmine cv. Parimullai (Jasminum auriculatumVahl) M.Sc. (Ag) Diss. Tamil Nadu Agric. Univ. Coimbatore.

5. Raman, K.R., Shanmugam, A. and Ahmad Sha, H. (1969).Studies on flowering habits and flower yields of some Jasminum species. South Indian Horticulture, 17: 18-27.

6. Raman, K.R. (1973). Studies on some aspects of flowering in Jasminum sambac.Ph.D Diss. Tamil Nadu Agric. Univ. Coimbatore.

7. Ranchana,P. and Kannan, M. (2015). Studies on Floral Biology of Tuberose (Polianthes tuberosa).Trends in Biosciences 8(6): 1435-1438.

8. Thomson, J. D. and Dommee, B. (2000). Morph-specific patterns of variation in stigma height in natural populations of distylous Jasminum fruticans.The New Phytologist, 148(2): 303-314.

\section{APPENDICES}

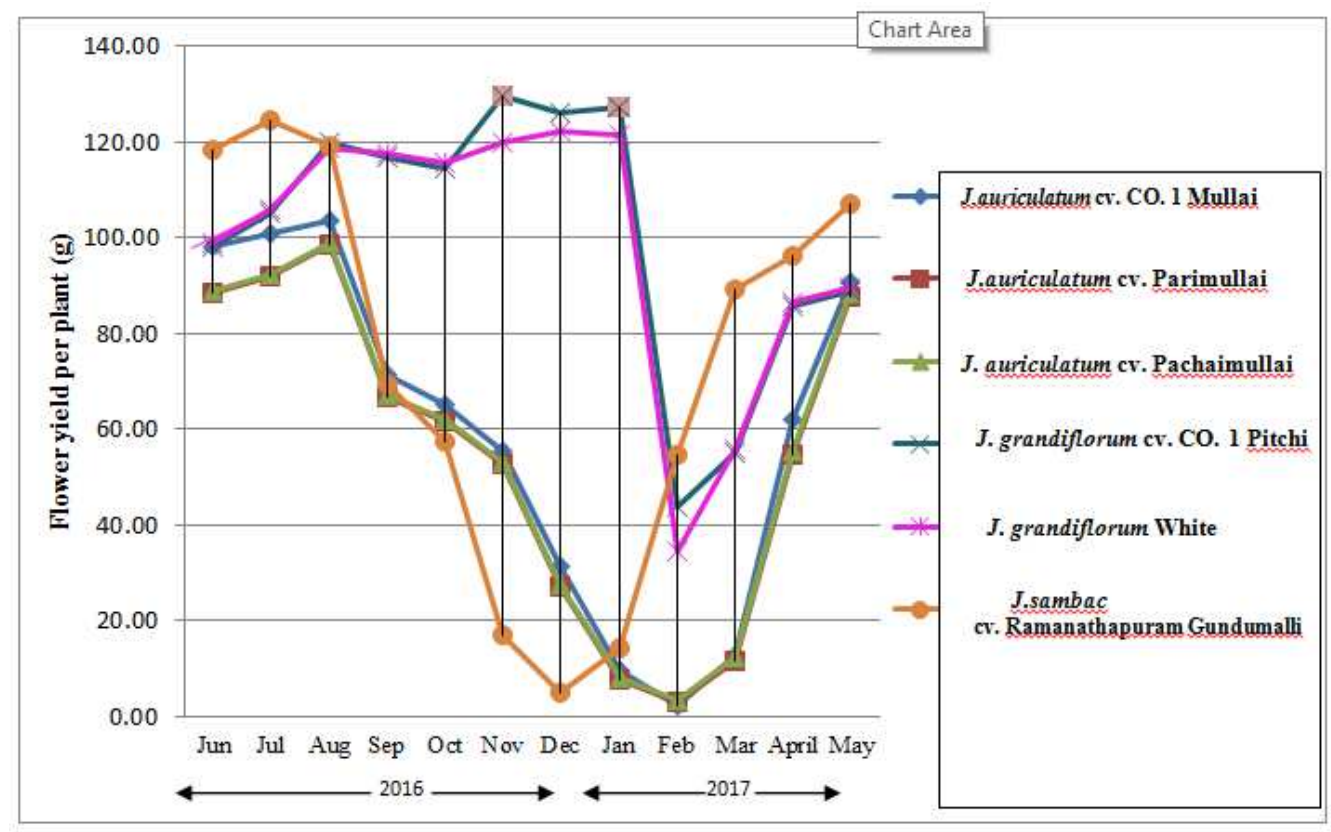

Figure 1: Monthly Flower Bud Yield Per Plant (g) of Jasmine Genotypes 
Table 1: Floral Biology Studies in Certain Commercial Genotypes of Jasmine (Jasminum spp.)

\begin{tabular}{|c|c|c|c|c|c|c|}
\hline \multirow[b]{2}{*}{ Characters } & \multicolumn{6}{|c|}{ Jasminum species } \\
\hline & $\begin{array}{l}\text { J. auriculatum } \\
\text { cv. CO.1 Mullai }\end{array}$ & $\begin{array}{l}\text { J. auriculatum } \\
\text { cv. Parimullai }\end{array}$ & $\begin{array}{l}\text { J. auriculatum } \\
\text { cv. Pachaimullai }\end{array}$ & $\begin{array}{l}\text { J. grandiflorum } \\
\text { cv. CO.1 Pitchi }\end{array}$ & $\begin{array}{c}\text { J. grandiflorum } \\
\text { cv. White }\end{array}$ & $\begin{array}{c}\text { J. sambac } \\
\text { cv. Ramanathapuram } \\
\text { Gundumalli }\end{array}$ \\
\hline Flower diameter $(\mathrm{cm})$ & 2.64 & 2.51 & 2.62 & 3.60 & 3.90 & 2.80 \\
\hline Corolla tube length & 1.82 & 1.94 & 1.81 & 2.32 & 2.45 & 1.36 \\
\hline Calyx type & Rudimentary & Rudimentary & Rudimentary & Well developed & Well developed & Well developed \\
\hline Mature flower bud colour & Creamy white & Creamy white & $\begin{array}{l}\text { White with } \\
\text { greenish tinge }\end{array}$ & Pink & White & White \\
\hline Open flower colour & White & White & White & White & White & White \\
\hline Number of whorls of corolla & 1 & 1 & 1 & 1 & 1 & 1 \\
\hline Number of petals per flower & 7 & 7 & 7 & 5 & 5 & 8 \\
\hline Number of pistils & 1 & 1 & 1 & 1 & 1 & 1 \\
\hline Style type & Exerted & Inserted & Exerted & Exerted & Exerted & Inserted \\
\hline Stigma tip & Undivided & Undivided & Undivided & Undivided & Undivided & Undivided \\
\hline Number of anthers & 2 & 2 & 2 & 2 & 2 & 2 \\
\hline Length of stamen $(\mathrm{cm})$ & 1.24 & 1.46 & 1.35 & 1.72 & 1.63 & 1.39 \\
\hline Ovary type & Bilocular & Bilocular & Bilocular & Bilocular & Bilocular & Bilocular \\
\hline \multicolumn{7}{|l|}{ Flowering pattern } \\
\hline (i) Peak flowering & Apr - Jun & Apr - Jun & Apr - Jun & Jul - Jan & Jul - Jan & Mar-Aug \\
\hline (ii) Lean flowering & Dec-Feb & Dec-Feb & Dec-Mar & Feb-May & Feb - May & Sep-Oct \\
\hline (iii) No flowering & Dec-Jan & Dec-Jan & Dec-Jan & - & - & Nov-Jan \\
\hline Fruit setting potential & Profuse & Profuse & Profuse & Sparse & Sparse & Absent \\
\hline Season of fruit set & Jun - Nov & Jun - Nov & Jun - Nov & Mar & Mar & Absent \\
\hline
\end{tabular}

